\title{
Study of combination of pumpkin seed flour and turkey meat in hams
}

\section{Oleg Galenko, Ostap Hasyuk,} Valentyna Kravchuk, Mariia Medianuk

\author{
National University of Food Technologies, Kyiv, Ukraine
}

Keywords:

Meat

Ham

Turkey

Pumpkin seed

Flour

Ham

Article history:

Received 28.11.2020

Received in revised

form 14.04.2021

Accepted 16.07.2021

\section{Corresponding}

author:

Oleg Galenko

E-mail:

galen@i.ua

DOI: $10.24263 / 2310-$

1008-2021-9-1-6

\section{Abstract}

Introduction. Studies have been conducted to determine the effect of combination of pumpkin seed flour and turkey meat in hams.

Materials and methods. The technology of hams with the use of mathematical modulation and addition to the composition of pumpkin seed flour and turkey meat was studies. Determination of amino acid composition was conducted in accordance with the method of ion exchange chromatography

Results and discussion. The share of muscle tissue in turkey carcasses of the 1 st and 2 nd grades is within $44-47 \%$ and is dominant, the skin content with subcutaneous fat is 13$22 \%$.

Determined that the protein content of oilseeds is indistinguishable from meat raw materials, and they can be considered as a good source of vegetable protein (19.4$34.2 \%)$.

Analysis of the amino acid composition of oilseeds proteins showed that they containe all essential amino acids, but there are minor differences in their quantitative content. In oilseeds, the predominant amino acid is leucine for sesame seeds, leucine and valine for sunflower seeds, phenylaline for pumpkin seeds.

Three experimental recipes for restructured ham were developed with the replacement of turkey meat with turkey skin in the amount of $10 \%$ and pumpkin seed flour in the amount of 5, 10, 15\% hydrated in a ratio of $1: 2$.

Physico-chemical studies have shown that ham made with the use of turkey skin and pumpkin seed flour have slightly higher protein content and more balanced ratio of protein and fat in the recipe $1: 1$, according to adequate nutrition,

Conclusions. The high quality of three formulations developed and tested for the production of restructured ham, in which $10 \%$ of turkey skin and $5-15 \%$ of pumpkin seed flour are combined, has been established. 


\section{- Food Technology -}

\section{Introduction}

Turkey meat is one of the most valuable types of meat, which is the most important source of complete animal protein, lipids with high levels of polyunsaturated fatty acids [6]. It has high dietary properties and taste qualities [7].

Food with turkey meat has high nutritional value, which means the ability to meet the body needs in proteins, lipids, minerals and vitamins [8]. Unlike pork and beef, turkey meat has high content of complete proteins because it has relatively little connective tissue, it is less coarse, hence fewer incomplete proteins (collagen and elastin) and is more easily exposed to hydrolysis when heat treated. Low fat content localized in the inner cavity of the carcass, intestines, stomach and subcutaneous layer reduces the likelihood of separation of fat in the production of ready-to-eat turkey meat products. Poultry fat tissue contains a large amount of polyunsaturated fatty acids $[1,2]$.

The muscle tissues of meat contain extractive substances and turkey chest muscles that are involved in the formation of taste and belong to strong activators of the secretion of gastric glands are especially rich of them. Turkey meat contains phosphorus in as big quantities as fish. In addition, turkey meat contains B and PP vitamins, the lack of which causes nervous and mental disorders, skin changes (ulcers, the effect of "orange" skin), leads to lower intelligence $[2,4]$

All these factors allow the use of turkey meat for the development of baby food, dietary, therapeutic food and food for functional nutrition of people. High biological value and dietary qualities of turkey meat products allow them to successfully compete with similar products containing pork and beef. research.

The possibility of combining turkey and pumpkin seeds in meat products requires

The purpose of research is to investigate the quality of meat products in which turkey and pumpkin seeds are added.

\section{Materials and methods}

\section{Flour preparation.}

Preparation of the flour of grains is to wash the grains with running water, soaking the grains in a water reservoir at a temperature of $18 \pm 2{ }^{\circ} \mathrm{C}$ for 8 hours, re-washing, sprouting grains in a reservoir without water at a temperature of $17 \pm 2^{\circ} \mathrm{C}$ for 3 days to the length of the $1 \mathrm{~cm}$ steer, drying the raw material to a moisture content of $16 \%$ and chopping up to a particle size of $0.2 \mathrm{~mm}-0.4 \mathrm{~mm}$. The size of the particles of the flour is determined by sifting it through a sieve with a passage of $0.2 \mathrm{~mm}$ to $0.4 \mathrm{~mm}$ grating openings [3].

\section{Determination of amino acid composition}

Determination of amino acid composition was conducted in accordance with the method of ion exchange chromatography [4]. Quality and quantitative determination of components consisted in dividing of them into separate components after the hydrolysis of proteins and determination of their quantitative estimation with the help of automatic analyzer of amino acids as T-339, on polystyrene sulfonate ion exchange resins of "Ostion LJ ANB" in Licitrate buffer one column mode. The elutions of amino acids from a column conduct in turn by Li- by citrate buffers from $\mathrm{pH} 2,75 \pm 0,01 ; \mathrm{pH} 2,95 \pm 0,01 ; \mathrm{pH} 3,2 \pm 0,02 ; \mathrm{pH} 3,8 \pm 0,02 ; \mathrm{pH}$ 
$5,0 \pm 0,2$. Amino acids rectifying with the help of solution of ninhydrin on a running photometer at a length of waves by $560 \mathrm{~nm}$. The results of detection was registered oneself by a variplotter on a paper in form the peaks of absorption of light of ninhydrin-positive substances in an eluate, that in number in direct ratio concentrations of this substance in solution. Correlation of solution of ninhydrin reagent and eluents is 1 to 2 ; temperature of thermostatic $\mathrm{T} 1=38,5^{\circ} \mathrm{C} ; \mathrm{T}=65^{\circ} \mathrm{C}$. The prototype was diluted in Li-citrate buffer by $\mathrm{pH}$ $2,2 \pm 0,02$ and inflicted on a ion exchange column with the help of metering device. The quantitative estimation of chromatograms of pre-production model settles accounts in relation to standard mixture of amino acids of firm VioRaD. The amount of milligrams of every amino acid of $\mathrm{Ai}$ in the investigated solution calculates on a formula:

$$
A i=\frac{M_{i} \cdot S_{i}}{S_{i}^{3}}
$$

where $\mathrm{Ai}$ is mass part of and-th amino acid, $\mathrm{mg} / 100 \mathrm{~g}$ of protein; Mi is molecular mass of $\mathrm{i}$ th amino acid; $\mathrm{Si}$ - is area of peak of and the amino acid on an aminogram from the investigated solution; is an area of peak of and amino acid on an aminogram from solution of standard mixture of amino acids, that accords to one micromole.

Amino acid SCORE is expected according to the certificate scale of THEO/WHO [12].

\section{Moisture content determining}

The moisture content was determined using the SuperPoint grain moisture meter, which is used for rapid analysis of grain moisture in laboratory and field conditions [13]. To measure the grain humidity, the appliance is switched on, the name of the scale of the corresponding measuring crop or product is selected on the LCD screen, the necessary sample is selected, which falls into the device, the pressure cover of the pressurizes to the level until the pressure indicator is set to the level with the upper surface of the lid. After tightening the button "TEST" is pressed and after 10 seconds the result of the measurements of humidity in $\%$ is received. Measurement is carried out with an accuracy of $0.5 \%$ with a range of humidity measurement from 8 to $45 \%$.

\section{Results and discussion}

\section{Study of the composition of the turkey}

The chemical composition of turkey meat depends on the type, age and category of feeding (Table 1) $[3,5]$.

By type and age, we distinguish meat of young poultry (cockerel) and adult poultry (turkey hen, turkey male).

Carcasses of young poultry have soft (cartilaginous) keel, soft beak, the lower part of which is easily bent, delicate elastic skin. The carcasses of cockerels have smooth skin on legs and underdeveloped spurs in the form of bumps. The carcasses of adult poultry have hard keel and keratinized beak. Turkey hen carcasses have rough skin on legs and male turkey carcasses have legs with hard spurs. Depending on the feeding and quality of post-slaughter processing the turkeys are divided into two categories of feeding -1 and 2 .

The grade of market quality (finish) is determined by the development of muscle tissue and keel bone (keel), amount of subcutaneous fat and the quality of skin treatment. 
Table 1

Chemical composition of turkey meat depending on the category of market quality (finish)

\begin{tabular}{|c|c|c|}
\hline \multirow{2}{*}{ Indicator } & \multicolumn{2}{|c|}{ Turkey meat } \\
\hline & 1st grade & 2nd grade \\
\hline \multicolumn{3}{|c|}{ Chemical composition, $g$ in $100 \mathrm{~g}$ of product: } \\
\hline Protein & 19.5 & 21.6 \\
\hline Fat & 22.0 & 12.0 \\
\hline Carbohydrates & - & 0.8 \\
\hline Ash & 0.9 & 1.1 \\
\hline \multicolumn{3}{|l|}{ Vitamins, in $100 \mathrm{~g}$ of product: } \\
\hline $\mathrm{A}, \mathrm{mg}$ & 0.01 & 0.01 \\
\hline ß-carotene, $\mathrm{mg}$ & Traces & Traces \\
\hline $\mathrm{E}, \mathrm{mg}$ & 0.34 & - \\
\hline $\mathrm{C}, \mathrm{mg}$ & - & - \\
\hline $\mathrm{B}_{6}, \mathrm{mg}$ & 0.33 & 0.33 \\
\hline $\mathrm{B}_{12}, \mathrm{mg}$ & - & - \\
\hline Biotin, micrograms & - & - \\
\hline Niacin, $m g$ & 7.8 & 8.0 \\
\hline Pantothenic acid, mg & 0.65 & - \\
\hline Riboflavin, mg & 0.22 & 0.19 \\
\hline Thiamine, $\mathrm{mg}$ & 0.05 & 0.07 \\
\hline Folacin, mg & 9.60 & 9.40 \\
\hline Choline, mg & 139 & 136 \\
\hline Energy value, kcal & 276 & 197 \\
\hline
\end{tabular}

Carcasses of 1st grade should have the following indicators:

- Muscle tissue is well developed;

- The shape of turkey breast is rounded. The keel bone is slightly protruded;

- Subcutaneous fat on turkey carcasses is on the breast and in the abdomen as well as a strip on the back;

- The quality of post-slaughter treatment of carcass must meet the following requirements: should be bloodless, with clean skin without feather, fluff, pins and hairlike feather, wax, scratches, breaks, stains, bruises and remnants of the intestine.

Eviscerated carcasses have oral cavity and beak cleaned from feed and blood, legs cleaned from dirt and spurs. Single feather pins and light rawness is allowed, no more than two skin cuts $1 \mathrm{~cm}$ long each.

Carcasses of the 2 nd grade must meet the following requirements:

- Muscle tissue is developed satisfactorily. The keel bone can stand out, breast muscles with keel bone make an angle without fold on its sides;

- Subcutaneous fat is insignificant: carcasses of cockerels and turkey hens have it in the lower back and abdomen;

- With quite satisfactory developed muscle tissue fatty subcutaneous fat may not exist;

- The skin of the 2th grade carcasses may have a small number of feather pins and rawness, no more than three skin cuts up to $2 \mathrm{~cm}$ long each. 
Poultry carcasses that meet the finish requirements of the 1st grade, and the quality of processing -2 grade, belong to the 2 nd grade.

In turkey meat, the ratio of protein and fat is close to optimal. However, turkey meat of grade 2 contains more protein and water but less fat than poultry meat grade 1 . The highest protein content and the least fat is in breast muscle $[5,7]$.

White turkey meat (breast muscles) differs from red (femoral muscles) with a lower lipid content, connective tissue and hemo-containing proteins.

Turkey meat compared to all other types of poultry meat is more rich in B vitamins and has the lowest cholesterol content.

The connective tissue of poultry meat has less strength than beef and pork, so it is much faster to hydrolysis during heat treatment. Given the high live weight of turkey and meatmaking qualities of carcasses, deep processing and sale of dressed turkey carcasses in in accordance with gastronomic purpose, economic feasibility, habits and requests of consumers is carried out.

Table 2 shows data of amino acid composition of turkey meat proteins [6].

Amino acid composition of turkey meat proteins

Table 2

\begin{tabular}{|l|c|c|}
\hline \multirow{2}{*}{ Indicator } & \multicolumn{2}{c|}{ Turkey meat } \\
\cline { 2 - 3 } & Grade 1 & Grade 2 \\
\hline Protein, \% & 19.5 & 21.6 \\
\hline $\begin{array}{l}\text { Amino acid composition, } \\
\text { g in 100 g protein }\end{array}$ & & \\
\hline Essential amino acids: & 39.10 & 39.55 \\
\hline Valine & 4.77 & 4.71 \\
\hline Isoleucine & 4.94 & 4.76 \\
\hline Leucine & 8.14 & 8.42 \\
\hline Lysine & 8.39 & 8.94 \\
\hline Methionine & 2.55 & 2.30 \\
\hline Treonine & 4.49 & 4.45 \\
\hline Tryptophane & 1.69 & 1.64 \\
\hline Phenylalynine & 4.12 & 3.94 \\
\hline Nonessential amino acids: & 60.69 & 60.54 \\
\hline Alanine & 6.25 & 6.12 \\
\hline Arginine & 5.99 & 6.45 \\
\hline asparagine acid & 10.30 & 9.75 \\
\hline Hystidine & 2.77 & 2.02 \\
\hline Glycine & 5.83 & 6.08 \\
\hline glutamic acid & 16.82 & 17.00 \\
\hline Oxyproline & 0.93 & 1.0 \\
\hline Proline & 4.26 & 4.21 \\
\hline Serine & 3.77 & 3.97 \\
\hline Tyrosine & 3.16 & 3.29 \\
\hline Cystine & 0.62 & 0.67 \\
\hline Total amino acids & 99.76 & 99.80 \\
\hline Limiting amino acid, skor, \% & No & No \\
\hline & & \\
\hline
\end{tabular}


Table 2 shows how high is the level of essential amino acids in turkey meat proteins. Food and biological value is determined by the significant content of essential amino acids, their optimal ratio, as well as good digestibility of meat by digestive tract ferments. Poultry meat proteins, particularly turkey meat, have no amino acids limiting the biological value of these proteins.

Based on this, it should be noted that poultry meat is the most important source of complete animal protein. Food proteins serve as building material for muscle tissue, ferments, hormones [8].

Lipids play important role in assessing the nutritional value of products. Lipids of poultry meat are carriers of energy, their biological value is determined by the content of polyunsaturated (essencial) fatty acids and fat-soluble vitamins. Fats provide good absorption of fat-soluble vitamins in intestine. They play an important role in the formation of meat taste.

Polyunsaturated fatty acids are not synthesized by human body in the required amounts. Fats with higher levels of unsaturated fatty acids contribute more to the absorption of proteic nitrogen. Turkey meat is a source of essential fatty acids, which are part of lipoprotein complex of human body cell membranes, so it is very important to ensure their supply in the required amount.

Poultry fats have melting point below $40^{\circ} \mathrm{C}$, which causes good emulsification in the digestive tract and absorption. Turkey lipids contain high levels of unsaturated fatty acids and especially precious polyunsaturated fatty acids - linoleic, linolenoic and arachidonic (Table 3).

One of the fractions that has the biggest share in the lipids of the edible part of turkey is represented by triglycerides [9].

When considering the fractional composition, the proportion of phospholipids is several times less than triglycerides, however, polyunsaturated fatty acids are found in phospholipids in greater quantities than in triglycerides.

The content of unsaturated fatty acids such as linoleic, linolenoic and arachidonic in turkey meat is almost 2 times bigger than saturated the same trend persists in relation to polyunsaturated essential fatty acids.

Different tissues of turkey meat are classified according to their industrial significance and distinguish between muscle, fat, connective, cartilage bone and blood. The main component of poultry meat is undoubtedly muscle tissue.

The share of muscle tissue in turkey carcasses of the 1 st and 2 nd grades is within 44 $47 \%$ and is dominant, the skin content with subcutaneous fat is $13-22 \%$ [10].

Poultry meat, particularly turkey, unlike meat of other farm animals, has varying degrees of muscle coloring: from clear pink (white meat) to dark red (red meat) depending on the content in pigment muscles. Red muscles contain less protein, more fat, cholesterol, phosphatids, ascorbic acid; in white muscles there's more carnosin, glycogen, adenosinetriphosphate. Myoglobin content in white muscles is $0.05-0.08 \%$, in red muscles several times more.

Turkey meat has the ability to take the taste of any other meat when used together. This feature of turkey meat is quite successfully used by many manufacturers of sausages, smoked meats, semi-finished products around the world [22]. 
Fractional and fatty acid composition of lipids in turkey meat

\begin{tabular}{|l|c|c|}
\hline \multirow{2}{*}{$\begin{array}{c}\text { Fractional and fatty acid composition of lipids, } \mathrm{g} \text { in } \\
\text { L of meat }\end{array}$} & \multicolumn{2}{c|}{ Turkey meat } \\
\cline { 2 - 3 } & Grade 1 & Grade 2 \\
\hline \multicolumn{1}{|c|}{ Saturated } & $\mathbf{2 2 . 0 0}$ & $\mathbf{1 2 . 0 0}$ \\
\hline Triglycerides & 16.06 & 8.40 \\
\hline Phospholipids & 4.40 & 3.00 \\
\hline Cholesterol & 0.21 & 0.13 \\
\hline Fatty acids (amount) & 18.35 & 9.12 \\
\hline \multicolumn{1}{|c|}{ Monounsaturated } & $\mathbf{5 . 8 2}$ & $\mathbf{2 . 9 1}$ \\
\hline including: & & \\
\hline C12:0 (lauric) & 0.02 & 0.01 \\
\hline C14:0 (myristic) & 0.23 & 0.11 \\
\hline C 3:0 p.m. (pentadecadionic) & 0.03 & 0.01 \\
\hline C 4:0 p.m. (palmitic) & 4.10 & 2.06 \\
\hline C 5:0 p.m. (margaric) & 0.07 & 0.03 \\
\hline C 6:0 p.m. (stearic) & 1.35 & 0.67 \\
\hline C20:0 (arachidic) & 0.02 & 0.02 \\
\hline & $\mathbf{8 . 4 6}$ & $\mathbf{4 . 2 3}$ \\
\hline including: & & \\
\hline C14:1 (myristoleic) & 0 & 0 \\
\hline C16:1 (palmitoleic) & 1.78 & 0.74 \\
\hline C17:1 (heptadecenoic) & 0.05 & 0.02 \\
\hline C18:1 (oleic) & 6.42 & 3.36 \\
\hline C20:1 (gadoleic) & 0.21 & 0.11 \\
\hline & $\mathbf{4 . 0 7}$ & $\mathbf{2 . 0 6}$ \\
\hline including: & & \\
\hline C18:2 (linoleic) & 3.88 & 1.98 \\
\hline C18:3 (linolenoic) & 0.15 & 0.06 \\
\hline C20:4 (arachidonic) & 0.04 & 0.02 \\
\hline & & \\
\hline
\end{tabular}

In addition, the muscle tissue of turkey meat has a fine-fiber structure without "marbling", which allows to bind up to $40 \%$ of moisture, thereby increasing the output of finished products. Turkey thigh meat consists of several small dark muscles that determine the texture of the entire piece of meat and finished products. Consequently, the thigh meat of the turkey is very thoroughly mixed when used with other types of meat. Zhylovane thigh meat is made with the help of special mechanical devices that remove 13 existing thigh hocks. As result, we get raw materials similar to beef crushed in hasher with $2-3 \mathrm{~mm}$ holes. This meat can replace with lean beef or pork, for example, in the production of salami [22].

Turkey meat is common in meat industry for the production of cutlet semi-finished products, sausages and specialty foods, but requires mechanical processing such as meat massaging or tumbling. Strength characteristics of turkey meat, especially the femoral part, come from big amount of connective tissue, the amount of which increases with the age of the bird. In young poultry meat collagen does not greatly affect hardness, but the older the bird the stiffer is the meat, because of collagen that forms heat-resistant transverse and intermolecular bonds inside one molecule, forming a heat-resistant spatial mesh, the presence 
of which causes the hardness of old birds meat. To increase the tenderness of turkey meat femoral part, different methods of mechanical processing, such as meat massaging or tumbling, are used. The promising trend is the use of enzyme preparations of plant and animal origin that have proteolytic activity, as well as probiotic cultures that secrete proteolytic enzymes capable of hydrolyzing the proteins of connective tissue [8].

The rapid growth of poultry meat production is due to the constant demand for it from consumers. There are no cultural or religious barriers for poultry meat. The consequence is the expansion of the range of products with poultry meat, the development of new recipes, new technologies that ensure the safety of products and their high quality.

Turkey meat contains all the necessary ingredients and can almost fully meet the needs of humans in animal protein. Given the high protein content and low fat, turkey meat can be used to produce cooked and smoked ham.

\section{Study of the chemical composition of pumpkin seeds}

The prospect for using oil-containing seeds to develop new meat products recepies is determined by its chemical composition. The chemical composition of oil-containing seeds crushed to a pasty mass is given in Table 4.

Chemical composition of oilseeds [8]

Table 4

\begin{tabular}{|l|c|c|c|}
\hline \multirow{2}{*}{ Indicator } & \multicolumn{3}{|c|}{ Mass fraction in the wall, \% } \\
\cline { 2 - 4 } & Sesame & Sunflower & Pumpkin \\
\hline Moisture & 9.0 & 8.0 & 5.2 \\
\hline Proteins & 19.4 & 20.7 & 34.2 \\
\hline Fats & 48.7 & 52.9 & 31.4 \\
\hline Carbohydrates & 12.2 & 10.5 & 17.6 \\
\hline Fiber & 5.5 & 5.1 & 6.2 \\
\hline Ash & 5.1 & 2.7 & 4.7 \\
\hline
\end{tabular}

According to Table 4 it is determined that the protein content of oilseeds is indistinguishable from meat raw materials, and they can be considered as a good source of vegetable protein (19.4-34.2\%). Protein content of pumpkin seeds exceeds meat protein content twice.

Sesame, sunflowers and pumpkin seeds contain a significant amount of vegetable fat (31.4-52.9\%), it is opportune for the development of new products (increasing the content of the mass fraction of fat in raw materials causes a decrease in moisture content in the finished product, which is a positive factor for its use in the recipe of meat products).

Oilseeds are a source of carbohydrates, the total content of which (starch, mono- and disaccharides) is $10.5-17.6 \%$. At the same time, plant raw materials also contain dietary fibers (up to $6.2 \%$ ).

Biological value of sesame, sunflower and pumpkin seeds is determined by the presence of essential amino acids in the protein part (Table 5) and fat acid composition (Table 6).

Analysis of the amino acid composition of oilseeds proteins, the results of which is presented in Table 3, showed that they containe all essential amino acids, but there are minor differences in their quantitative content. In oilseeds, the predominant amino acid is leucine for sesame seeds, leucine and valine for sunflower seeds, phenylaline for pumpkin seeds. 
Content of essential amino acids in plant raw materials

\begin{tabular}{|c|c|c|c|}
\hline \multirow{2}{*}{$\begin{array}{c}\text { Essential amino acid } \\
\text { (EAA) }\end{array}$} & \multicolumn{3}{|c|}{ Content, mg/100 g } \\
\hline & Sesame & Sunflower & Pumpkin \\
\hline Isoleucine & 783.0 & 694.0 & 656.7 \\
\hline Leucine & 2338.0 & 1343.0 & 1792.0 \\
\hline Lysine & 1074.0 & 710.0 & 624.6 \\
\hline Methionine & 559.0 & 690.0 & 824.0 \\
\hline Treonine & 1468.0 & 885.0 & 1601.0 \\
\hline Phenylalynine & 1785.0 & 1149.0 & 2045.0 \\
\hline Valine & 1296.0 & 1471.0 & 752.5 \\
\hline Tryptophan & 590.0 & 348.0 & 389.2 \\
\hline$\Sigma$ EAA & 9893.0 & 7290.0 & 8685.0 \\
\hline
\end{tabular}

Fatty acid composition of plant raw materials

Table 6

\begin{tabular}{|l|c|c|c|}
\hline \multirow{2}{*}{ Fatty acids } & \multicolumn{4}{|l|}{ Content, \% to the total content of fatty acids } \\
\cline { 2 - 4 } & Sesame & Sunflower & Pumpkin \\
\hline Saturated & & & \\
\hline Palmitic $\left(\mathrm{C}_{16: 0)}\right.$ & 4.20 & 3.22 & 10.51 \\
\hline Stearic $\left(\mathrm{C}_{18: 0)}\right.$ & 2.20 & 3.90 & 5.37 \\
\hline Monounsaturated & & & \\
\hline Miristoleic $\left(\mathrm{C}_{14: 1}\right)$ & 0.44 & 0.52 & 0.35 \\
\hline Palmitoleic $\left(\mathrm{C}_{16: 1}\right)$ & 0.10 & 0.20 & 0.10 \\
\hline Oleic $\left(\mathrm{C}_{18: 1}\right)$ & 25.40 & 17.60 & 44.69 \\
\hline Polyunsaturated & & & \\
\hline Linoleic $\left(\mathrm{C}_{18: 2}\right)$ & 19.61 & 42.83 & 35.10 \\
\hline Linolenoic $\left(\mathrm{C}_{18: 3}\right)$ & 0.13 & 0.20 & 0.15 \\
\hline Arachidonic $\left(\mathrm{C}_{20: 4}\right)$ & 0.7 & 0.90 & 1.30 \\
\hline
\end{tabular}

According to Table 3, it is determined that nonsaturated fatty acids (oleic and linoleic) that are involved in the formation of cell membranes and shells of nerve fibers prevail in oilseeds.

In addition, oilseeds have good mineral and vitamin composition: sesame seeds contain large amount of calcium, magnesium and phosphorus, vitamins PP, $\mathrm{B}_{2}$; sunflower seeds are rich in selenium and vitamins $\mathrm{E}$ and $\mathrm{B}_{1}$;pumpkin seeds contain in large quantities potassium, zinc, phosphorus and iron. Being rich in amino acids, fatty acids and minerals, the selected plant raw materials can be considered as an additional source of functional components with improved technological characteristics.

Pumpkin (Cucurbita) is genus of annual and perennial herbaceous plants, xenogamous, belongs to gourd family. Cucurbits are native to North and South America, where they are cultivated from the 3rd millennium BC. It is heat-loving, drought-resistant, relatively shadetolerant plant. Pumpkin is juicy multi-seed fruit with yellow or orange pulp, from 15 to 40 $\mathrm{cm}$ in diameter. Seeds amount to $0.75-5 \%$ of its weight. The seeds are flat, elliptical, little narrowed on one side, 10-12 mm long. Outer shell is dense, woody, yellowish-white; inner 
shell is scarious, greenish-gray. The seeds are without endosperm, large embryo consists almost entirely of two cotyledons. The taste of cotyledons is pleasant, buttery, sweetish. The seed shell makes in average $20-32 \%$ of the seed weight. The weight of 1000 dry seeds is $140-350 \mathrm{~g}$.

Mainly, three species of pumpkin are cultivated: cucurbita maxima, cucurbita pepo and cucurbita moschata.

Cucurbita maxima is the most cold-resistant, but more late ripening variety than cucurbita pepo. Fruits are characterized by large size, long storage time, good flavours and multi-seeds (100-300g). The seeds are large (small ones are rare), milky white or brown depending on the variety, smooth, with an obscure border.

Cucurbita pepo is well adapted to sharp temperature fluctuations. The fruits are small, with hard rind and strigose subulate downiness. Seeds are usually of medium size or small, very rarely large, clear yellow or yellowish color, with a border of the same color [16].

Cucurbita moschata is the most heat-loving and late ripening one. The fruits are small and medium, of elongated shapes, narrowed in the middle. The fruit pulp is orange, with a nutmeg flavor. The seeds are elongated, medium or small, creamy or gray, with a border darker than the color of the seeds.

Unlike other crops, melons and, in particular, pumpkins are characterized by universal use. They are processed in canneries, used in medicine and pharmacology.

Due to the high content of sugars and biologically active substances, good taste characteristics, easy digestibility, pumpkin pulp has high nutritional and medicinal properties. The fruit pulp contains 70-94\% water and 6-30\% dry matter that contains 1.5 $15 \%$ sugars; $4-23 \%$ fiber and hemicellulose; up to $24 \%$ starch; from 0.3 to $1.5 \%$ of pectins: $1-3 \%$ of nitrogenous substances; $0.5-0.7 \%$ crude fat, $0.1 \%$ acids; $0.4-1.4 \%$ ash; $25-40 \mathrm{mg} \%$ ascorbic acid; $2-28 \mathrm{mg} \%$ of $\beta$-carotene $[10,13]$.

For the processing enterprises the pumpkin is convenient in use because thanks to existence of dense pulp and biochemical features of structure, it is capable to be stored without deterioration of quality within $3-6$ months $[11,12]$. This allows you to reduce the seasonality of enterprises and load production in the autumn-winter period. During storage, the pumpkin ripens, besides the starch is hydrolyzed, the sugar content increases, its taste and nutritional properties improve.

Pumpkin is processed into pureed canned food for baby food and general purpose. Pumpkin is used for production of semi-finished products (boiled puree); it is used for juice production and pumpkin drinks blended with apricot, apple juices, flavored with orange oil, etc. Pumpkin is a valuable raw material for the production of pectin [14].

A by-product in the production of the above products are pumpkin seeds, which, at best, are used for livestock feed. At the same time, pumpkin seeds have a unique chemical composition and pharmacological properties, which are given to them by oil contained in the seeds. Pumpkin seed oil was recognized in the 1930 s as a table product of industrial significance [9] (Table 7).

Table 7

Chemical composition of pumpkin seeds

\begin{tabular}{|l|l|c|}
\hline No & \multicolumn{1}{|c|}{ Composition } & Content (\%, in equivalent to dry substances) \\
\hline 1 & Water & $6.02-6.50$ \\
\hline 2 & Lipids & $34.08-38.0$ \\
\hline 3 & Protein $(\mathrm{N}-6,25)$ & $31.0-32.5$ \\
\hline 4 & Cellulose & $13.58-18.10$ \\
\hline 5 & Soluble carbohydrates & $9.00-10.38$ \\
\hline
\end{tabular}


The content of oil in the kernel (in a shell-free seed) is $47.43-54.56 \%$.

Phytosterol cucurbitol $\mathrm{C}_{27} \mathrm{H}_{46} \mathrm{O}$, hydrocarbon $\mathrm{C}_{30} \mathrm{H}_{62}$ and oxycerotinic acid are found in the oil $\mathrm{C}_{26} \mathrm{H}_{52} \mathrm{O}_{3}$.

The oil has a high content of biologically active substances, it contains 53 micro- and macroelements, carotene (provitamin A), tocopherols (vitamin E), vitamins B, PP and P [15] (Table 8, 9).

Fatty acid composition of triacilglycerols of pumpkin oil

Table 8

\begin{tabular}{|l|l|c|}
\hline No & \multicolumn{1}{|c|}{ Composition } & Content (\% of fatty acids) \\
\hline 1 & Palmitic $\mathrm{C}_{16: 0}$ & $6.0-12.5$ \\
\hline 2 & Palmitoleic $\mathrm{C}_{16: 1}$ & $0.5-0.6$ \\
\hline 3 & Stearic $\mathrm{C}_{18: 0}$ & $5.86-7.50$ \\
\hline 4 & Eicosanoic $\mathrm{C}_{20: 0}$ & 0.003 \\
\hline 5 & Oleic $\mathrm{C}_{18: 1}$ & $26.0-36.0$ \\
\hline 6 & Linoleic $\mathrm{C}_{18: 2}$ & $40.0-55.0$ \\
\hline 7 & Docosanoic (behenic) $\mathrm{C}_{22: 0}$ & $0.2-0.25$ \\
\hline
\end{tabular}

Vitamin $\mathrm{E}$ is represented by a mixture of polyunsaturated fatty acids oleic, linoleic and linolenic, the content of which is up to $70 \%$. Provitamin A in oil is represented as the sum of various carotinoids whose content is from 10 to $15 \mathrm{mg} \%$. Vitamin $\mathrm{E}$ in pumpkin seed oil is in the amount of $94 \mathrm{mg} \%$ and it is represented mainly by $\alpha$-tocopherol (76\%). Vitamin $\mathrm{E}$ is one of the strongest natural antioxidants, which is of great importance for the living organism and provides high biological activity and quite good resistance to oxidation during oil storage.

\section{Content of micro- and macroelements in pumpkin oil}

Table 9

\begin{tabular}{|l|l|c|}
\hline No & Composition & Content, mg\% \\
\hline 1 & Iron & $13-15$ \\
\hline 2 & Magnesium & $3-4$ \\
\hline 3 & Zinc & $8-10$ \\
\hline 4 & Selenium & $5-6$ \\
\hline
\end{tabular}

\section{Conclusion}

1. The chemical composition, functional, technologicalo structural and mechanical properties of pumpkin seed flour and their change under the influence of technological parameters (table salt in solution, $\mathrm{pH}$, temperature), including in combination with turkey meat, have been studied.

2. Qualitative indicators of turkey meat and skin, their chemical composition, functional and technological properties (moisture-binding, moisture-holding, fat-retaining, emulsifying ability, emulsion stability) were studied. The chemical composition of 


\section{Food Technology}

turkey skin as a fat component of the meat emulsion was studied as turkey skin is a valuable raw material for production of ham.

3. Three experimental recipes for restructured ham were developed with the replacement of turkey meat with turkey skin in the amount of $10 \%$ and pumpkin seed flour in the amount of $5,10,15 \%$ hydrated in a ratio of $1: 2$.

4. Physico-chemical studies have shown that ham made with the use of turkey skin and pumpkin seed flour have slightly higher protein content and more balanced ratio of protein and fat in the recipe 1: 1, according to adequate nutrition,

5. Conducted functional and technological studies have shown that experimental ham is characterized by an increase in moisture-retaining and fat-retaining capacity. The test samples have the best moisture-binding, moisture-retaining, fat-retaining characteristics by $15 \%$.

\section{References}

1. Jochen Weiss, Monika Gibis, Valerie Schuh, Hanna Salminen, (2010), Advances in ingredient and processing systems for meat and meat products, Meat Science, 86(1), pp. 196-213.

2. Peshuk L., Galenko O., Sergina V. (2015) Technology for meat gerodietetic products, Ukrainian Journal of Food Science, 3 (1), pp. 16-26.

3. Alison J. McAfee, Emeir M. McSorley, Geraldine J. Cuskelly, Bruce W. Moss, Julie M.W. Wallace, Maxine P. Bonham, Anna M. Fearon, (2010), Red meat consumption: An overview of the risks and benefits, Meat Science, 84(1), pp. 1-13.

4. Huang S.C., Tsai Y.F., Chen C.M. (2011), Effects of wheat fiber, oat fiber on sensory and physico-chemical properties of Chinese-style sausages, Asian-Australian Journal of Animal Science, 24(6), pp. 875-880

5. Bou R., Codony R., Tres A., Decker E.A., Guardiola F. (2009), Dietary strategies to improve nutritional value, oxidative stability, and sensory properties of poultry products, Critical Review on Food Science and Nutrition, 49(9), pp. 800-822

6. Peshuk L., Galenko O. (2011), Gerodietic meat products technology enriched with calcium and phosphorus, Food and Environment Safety, X(4), pp. 18-23.

7. Ismail, I., Huda, N., Ariffin, F. (2014). Quality characteristics of spent duck sausages containing surimi like material substitution during refrigerated storage. International Journal of Poultry Science, 13(4), pp. 228-239.

8. Radzievska I., Melnyk O., Galenko O., Peshuk L. (2018), Two-stage technology for palm oil fractionation for production of cocoa butter substitutes, Nauka innov., 14(1), pp. 40-49.

9. Peshuk L., Galenko O., Androsova A., Bogun V. (2016) Meat products for the nutrition of people with the overweight of body - pandemic of XXI century, Ukrainian Journal of Food Science, 4(1), pp. 6-17.

10. Hutchison C.L., Mulley R.C., Wiklund E., Flesch J.S. (2012), Effect of concentrate feeding on instrumental meat quality and sensory characteristics of fallow deer venison, Meat Science, 90(3), pp. 801-806.

11. Kim C. J., Kim H. W., Hwang K. E., Song D. H., Ham Y. K. et al. (2016), Effects of dietary fiber extracted from pumpkin (Cucurbita maxima Duch.) on the physico-chemical and sensory characteristics of reduced-fat frankfurters, Korean J. Food Sci. Ani. Resour., 36, pp. 309-318.

12. Choi Y. S., Kim H. W., Hwang K. E., Song D. H., Park J. H. et al. (2012), Effects of pumpkin (Cucurbita maxima Duch.) fiber on physicochemical properties and sensory characteristics of chicken frankfurters, Korean J. Food Sci. Ani. Resour., 32, pp. 174-183. 


\section{- Food Technology —}

13. Sheshnytsan Y. N. (2012), Zhyrnokyslotnыi sostav masla semian tыkvы, Yzvestyia Samarskoi hosudarstvennoi selskokhoziaistvennoi akademyy, 4, pp. 103-106.

14. Kraievska S. P. (2013), Analiz khimichnoho skladu nasinnia harbuza, kunzhutu ta lonu yak perspektyvnykh dzherel dlia vyrobnytstva biolohichno aktyvnykh dobavok do yizhi, Stratehyia kachestva v promblshlennosty y obrazovanyy: IKh Mezhdunar. konf., 31 maia-7 yiunia 2013 h. Varna, pp. 95-97.

15. Veličković D. T., Ristić M. S., Karabegović I. T. et al. (2015), Volatiles and fatty oil of Cucurbita maxima, Advanced technologies, 4(2), pp. 43-48. 